\title{
Effect of Neuro-Linguistic Programming (NLP) on Anxiety: A Systematic Literature Review
}

\section{Rifki S. Nompo ${ }^{1}$, Andria Pragholapati², and Angela L. Thome ${ }^{3}$}

${ }^{1}$ Ners Professional Education Program, Stikes Jayapura, Papua, Indonesia

${ }^{2}$ Department of Nursing, Universitas Pendidikan Indonesia, Bandung, Indonesia

${ }^{3}$ Bachelor of Nursing Program, Stikes Jayapura, Papua, Indonesia

ORCID:

Rifki S. Nompo: https://orcid.org/0000-0002-5821-7179

\section{Abstract}

Anxiety is a feeling of helplessness, and worry about things that are not clear, as well as a comprehensive feeling that something bad is going to happen. Anxiety is experienced subjectively and communicated interpersonally, at the same time feelings of anxiety are a necessary survival instinct. The Neuro-Linguistic Programming (NLP) is a communicative approach employs a positive view of anxiety and how it can help shape life changes, and that is the topic of this article. This research method uses a Systematic

Corresponding Author: Rifki S. Nompo

sakinah@stikesjypr.ac.id

Published: 15 March 2021

Publishing services provided by Knowledge E

(c) Rifki S. Nompo et al. This article is distributed under the terms of the Creative Commons Attribution License, which permits unrestricted use and redistribution provided that the original author and source are credited.

Selection and Peer-review under the responsibility of the IVCN Conference Committee. Literature Review, investigating Garuda, Pubmed, ScienceDirect, and Proquest, using boolean for keyword neurolinguistics programming (NLP) and anxiety. The inclusion criteria used were Indonesian and English language articles written within the last 5 years (from 2015 until 2020). The exclusion criteria used by the article were abstract writing style, inaccessible, or lacking national accreditation. Articles were tested with Critical Appraisal Tools. The studies indicate that good communication using NLP can help reduce anxiety and can promote changes in a person's behavior patterns. There are several NLP techniques including sensory acuity, reframing, anchoring, rapport, and pacing, and leading. NLP can improve knowledge, skills and attitudes, communication skills, self-management, mental health, reduce work stress, and self-efficacy.

Keywords: Anxiety, Neuro-Linguistic Programming, NLP

\section{Introduction}

Anxiety is an emotion or some feelings of tension, with negative thoughts, or annoying worries. Some people can avoid this situation by maintaining coping, anxiety is usually accompanied by physical symptoms such as sweating, trembling, dizziness, and fast heartbeat [1].

According to The World Health Organization [2] explain that depression and anxiety are common mental disorders with highest prevalence. More than 200 million people worldwide (3.6\%) suffer from anxiety while depression totals 322 million people 
worldwide (4.4\%) and nearly half of them are from the Southeast Asia and West Pacific region.

The meta-analysis study showed that the general prevalence of anxiety in China was 0.9\%, while in Afghanistan 28.3\%, Italy 2.4\%, and Mexico 29.8\%, data for the global prevalence in 2013 was 7.3\%, that is 1 in 14 people worldwide can suffer from an anxiety disorder and 1 person in 9 will experience an anxiety disorder each year [3].

In Indonesia, according to the results of the Basic Health Research (Riskesdas) in 2013 , it showed that $6 \%$ of the population aged 15 years and over around 14 million people in Indonesia experienced mental-emotional disorders which manifest as anxiety and depression disorders [4].

Anxiety is experienced by individuals subjectively and communicated interpersonal, anxiety is necessary to survive, but the level of severe anxiety is not in line with life. Anxiety can arise when individuals face new experiences such as entering school, starting a new job, or giving birth to a baby $[5,6]$.

Neuro-Linguistic Programming (NLP) is a communication approach aimed at individuals with the goal of change and the biggest role of NLP therapy is to help humans communicate better with themselves, reduce fear without reason, can control negative emotions and feelings of anxiety. Neuro refers to a neurological system based on interpreted ideas and the experiences around them. Linguistics is an element that refers to how the influence of words and body language can affect the lives of others. Programming is an element that refers to individual experiences that involve "internal code". This includes the internal processes, strategies, and mindset used to make decisions, solve problems, and assist in individual learning [7].

Since the 1970s NLP has been developed and modified by various practitioners, and its application extends to various fields of life. Then Richard Bandler developed Design Human Engineering (DHE) and Neuro-Hypnotic Repatterning, while Grinder developed New Code. Both of them successful made model figures internal structure models for anyone onto a concept called NLP [19, 20].

In Indonesia, NLP has started to develop gradually, especially in the field of education where its use is applied in counseling or during consultations. In some countries like Afrika, Malaysia, Iran, dan Turki, NLP increasing as one of the competencies because it is the most effective form of soft skills development training, and NLP has also been applied in the learning process and has proven to make students understand each other and achieve better learning outcomes [19].

Research finds that neuro-linguistic programming has a good role, this study shows that neuro-linguistic programming training is proven to be effective in overcoming 
individual problems by increasing the use of individual strategies including involving coping strategies in it [8].

Learning about how individual minds work which can then be changed to be able to improve the quality of individual life to be productive, a communication model regarding the individual's internal condition based on experience and communication both inter and or intrapersonal which is then linked to the concept of reality so that it can increase the use of individual strategies including involving coping strategies therein [7]

From the description above, the researcher is interested in researching the effect of neuro-linguistic programming (NLP) on people who have anxiety through various scientific articles that have been proven based on EBP (Evidence Based Practice).

\section{Methods and Equipment}

\subsection{Methods}

\subsubsection{Search the Literature}

Database atau search engines menggunakan Garuda, Pubmed, Sciencedirect, dan Proquest. Strategi pencarian menggunakan kata kunci "Rumah Sakit" OR "Hospital" OR "NLP" OR "Neuro Linguistic Programming", "Kecemasan" OR "Ansietas" OR "Anxiety" OR "Dubt" OR "Nervousness", "NLP AND "Kecemasan", "NLP” AND "Anxiety”, "NLP" AND "Dubt", "NLP" AND "Nervousness", "NLP" OR "Neuro Linguistic Programming" AND "Kecemasan" OR "Ansietas" OR "Anxiety" OR “Doubt” OR "Nervousness".

TABLE 1: Data Sources and Seach Strategy for Practices

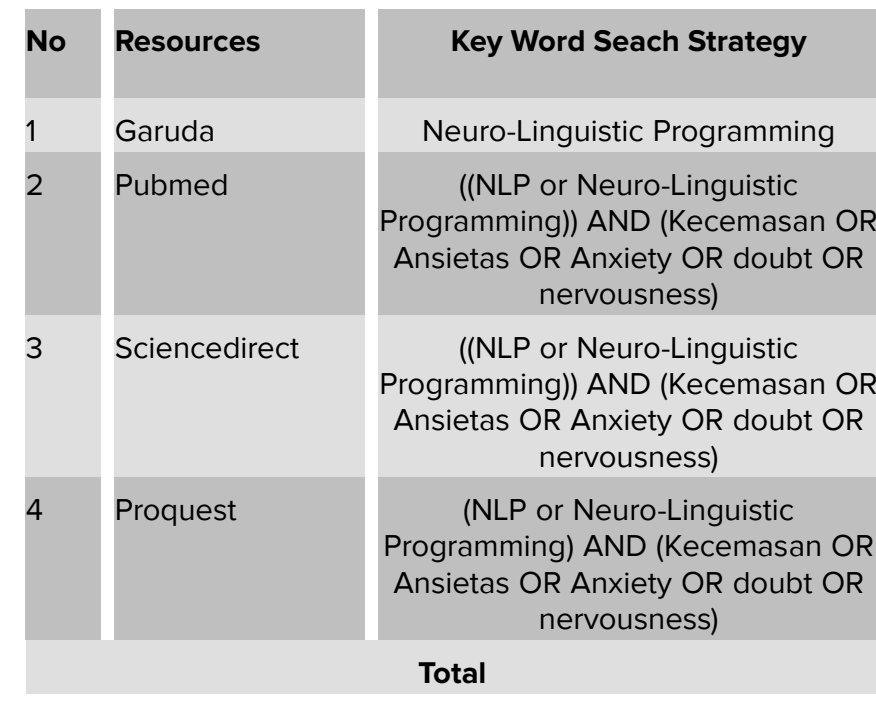

\begin{tabular}{|c|c|c|}
\hline $\begin{array}{c}\text { Total } \\
\text { Results }\end{array}$ & $\begin{array}{c}\text { Primary } \\
\text { Selection }\end{array}$ & $\begin{array}{c}\text { Final } \\
\text { Selection }\end{array}$ \\
\hline 27 & 14 & 7 \\
\hline 10 & 4 & 1 \\
\hline 61 & 21 & 0 \\
\hline 1206 & 5 & \\
\hline & & \\
\hline 1304 & 44 & 8 \\
\hline
\end{tabular}




\subsubsection{Literature Selection}

TABLE 2: Criteria Inclusion and Exclusion

\begin{tabular}{l|l}
\hline Criteria Inclusion & Criteria Exclusion \\
\hline Indonesian and English & Abstract \\
\hline The last 5 years from 2015 to 2020 & Inaccessibible \\
\hline Tipe: free full teks, book and review & Anaccredited Nationally
\end{tabular}

\subsubsection{Data Extraction and Synthesis}

The following data was extracted from each publication: Date of review, Title, Reference, Database, Practices/Solutions: Effect of neuro-linguistic programming (NLP) on anxiety, Methodology (studi meta-analisis, ekperimental, non-ekaperimental, studi kasus, and literature review), Target Population, Sample Population, Publication Quality Description, Country/location of the Analysis and Year. All articles tested with Critical Appraisal Tools.

The data synthesis phase was done by the primary reviewer (the primary author) with the help of secondary reviewer (the co-author). We have identified 8 practices/solutions from the sample of 44 papers for addressing effect of neuro-linguistic programming on anxiety.

\section{Results}

\subsection{Study Setting}

The study was identified from databases Garuda, PubMed, Science Direct, and ProQuest there obtained $n=1304$ articles, then articles were identified based on duplication of $n=1304$ with the inclusion criteria used were Indonesian and English language, the last article's research was 5 years from 2015 until 2020. The exclusion criteria there were $n=1260$ articles, articles used form of abstract, inaccessible, and not accredited. Furthermore, screening is carried out based on the identification of the title into $n=$ 44 articles, and re-exclusion based on the suitability of the research aim into $n=36$ articles, and the final filter is based on identification, full text and eligibility criteria, then the articles that are suitable and can be used are $n=8$ articles. 


\begin{tabular}{|c|c|c|c|c|c|}
\hline 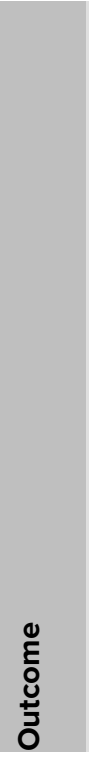 & 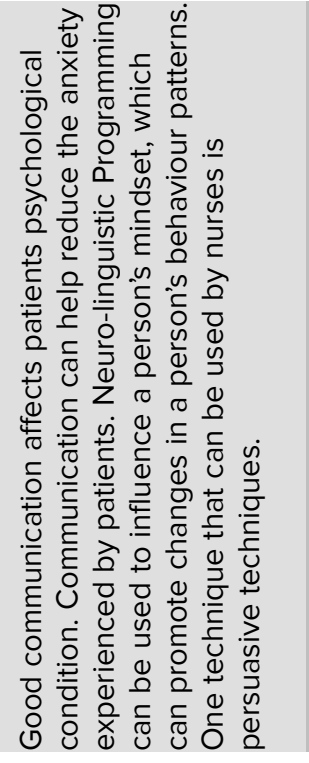 & 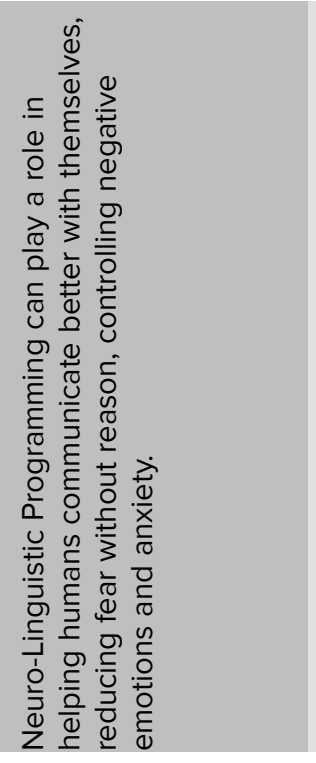 & 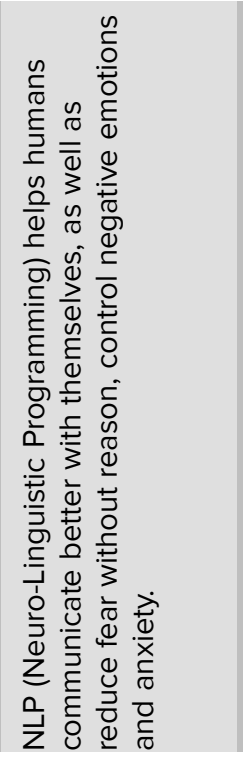 & 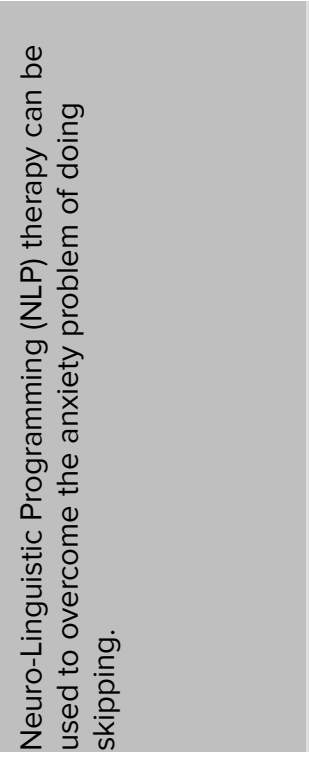 & 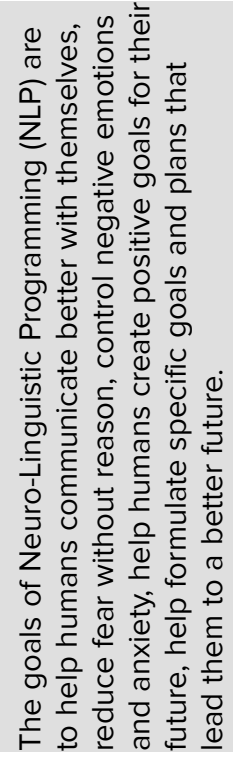 \\
\hline 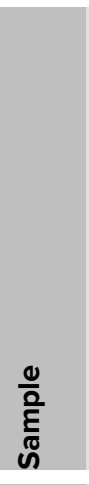 & 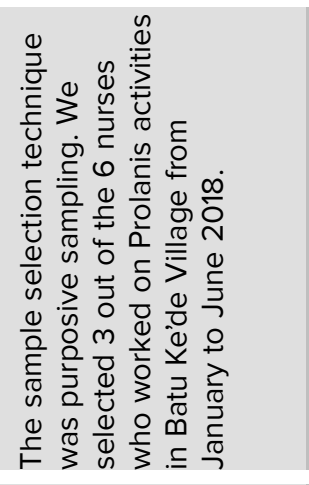 & 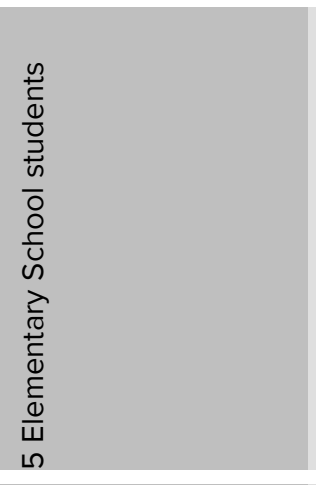 & 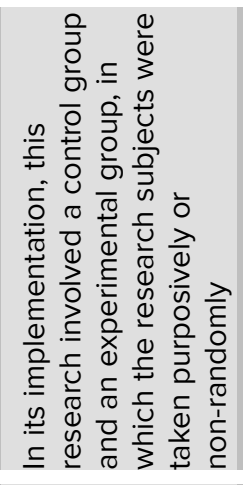 & 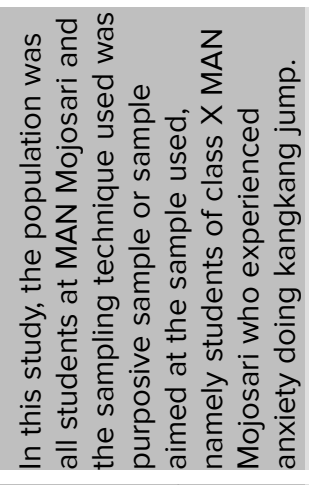 & \\
\hline 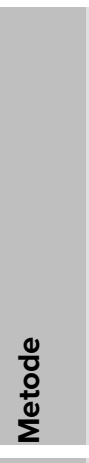 & 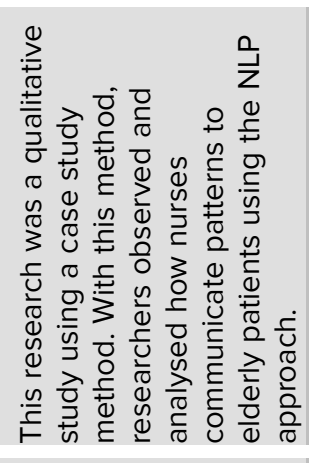 & 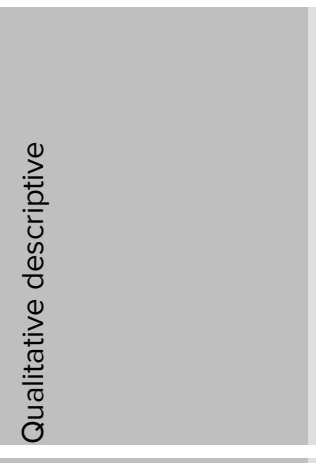 & 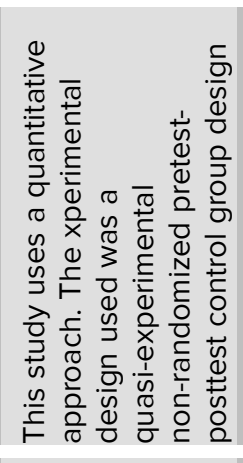 & 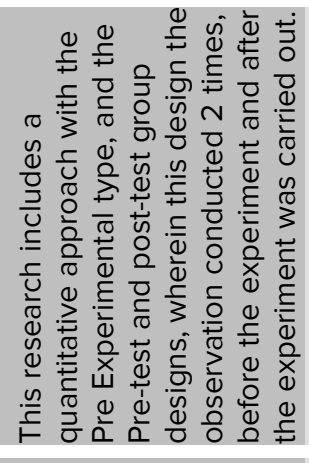 & 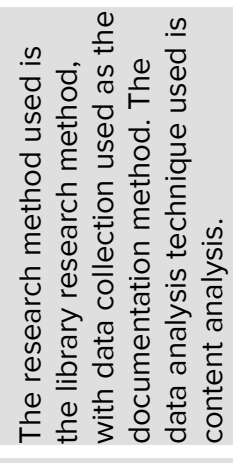 \\
\hline 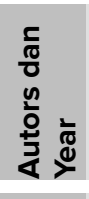 & 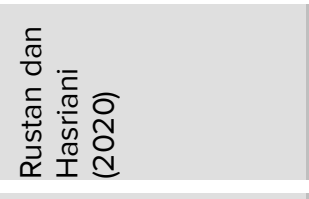 & 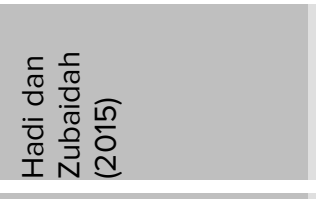 & 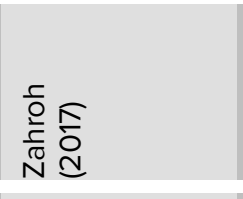 & 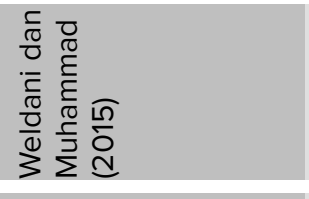 & 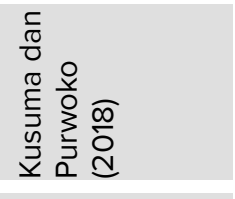 \\
\hline $\begin{array}{l}\overline{\bar{z}} \\
\bar{\jmath}\end{array}$ & 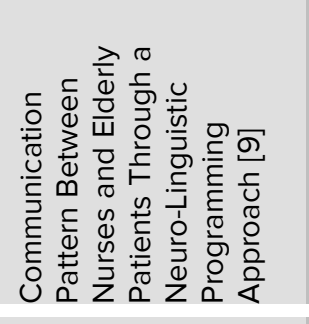 & 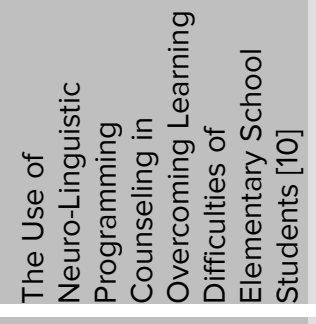 & 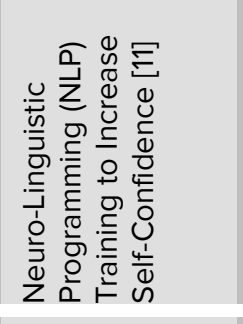 & 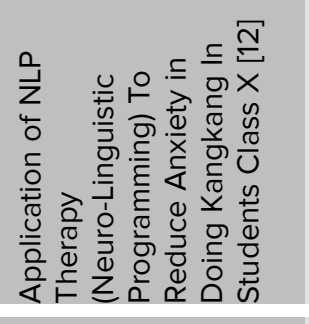 & 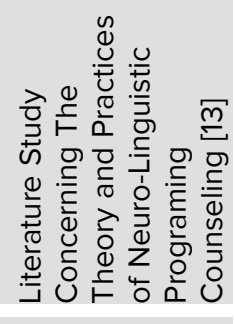 \\
\hline zo & - & & & & \\
\hline
\end{tabular}




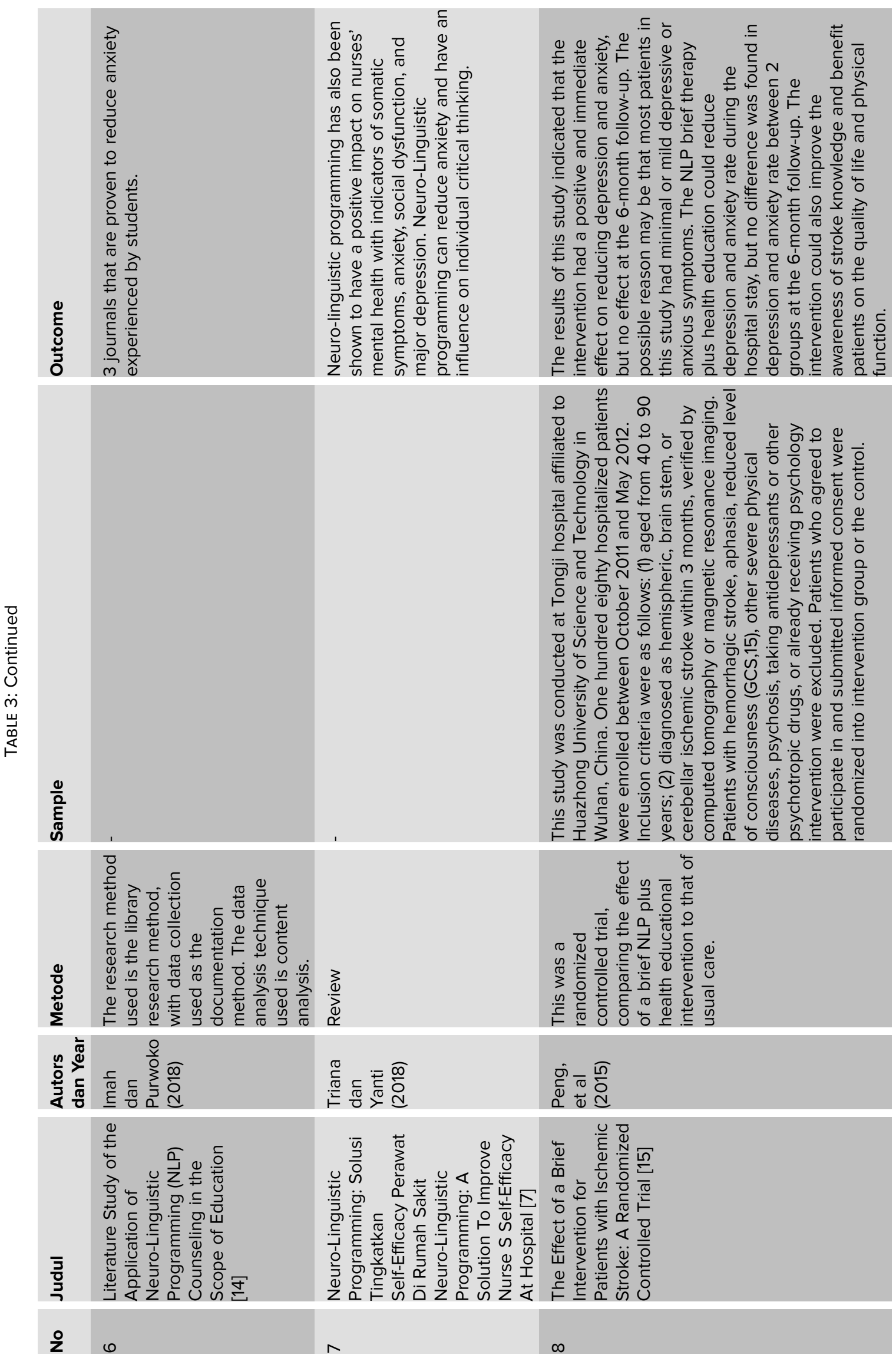



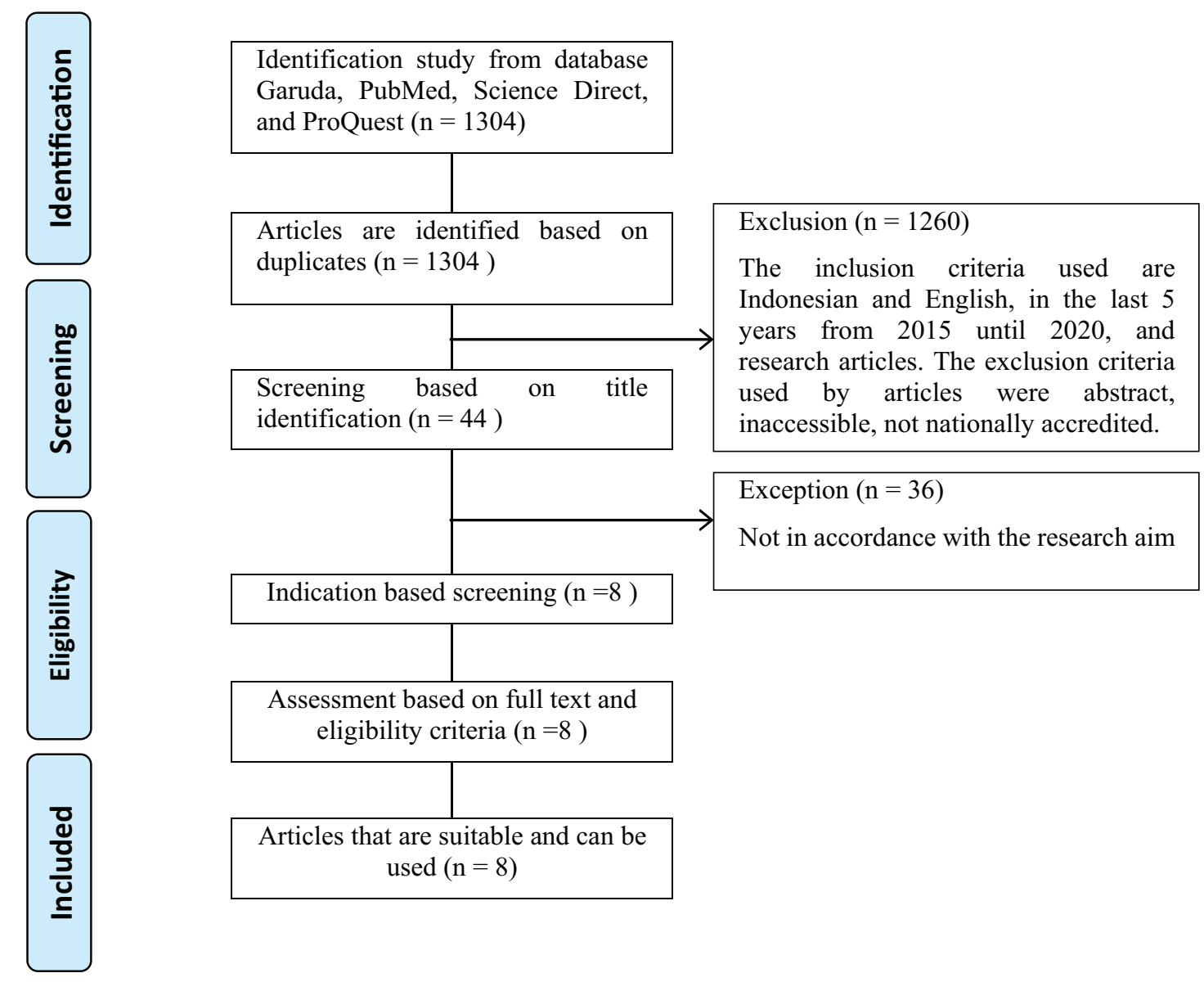

Figure 1: PRISMA 2009 Flow Diagram

\section{Discussion}

The results were 8 journals that match the inclusion criteria. 7 articles from the Garuda journal and 1 article from the Pubmed journal. Articles with qualitative methods have two articles, quantitative experimental methods have two articles, and literature reviews have three articles.

Communication is a bridge between one individual and another so that interaction and socialization occur. Even in nursing, communication becomes the core in conveying a sense of empathy and as an optimal form of care, there are several communication techniques that can support a nurse to improve her quality, one of which is by using NLP [13]. Combining verbal language with body language can make two-way communication run smoothly and easily for accepted by the communicant. The success of a communication determined by the use of verbal language (words), vocals (intonation), and visuals so communication will run perfectly. 
Good communication using NLP can help reduce anxiety and can promote changes in people's behavior patterns. NLP has other influences such as realistic perceptions of self, self-esteem, emotional and behavioral control [7, 9, 12].

NLP classifies human types into 3 groups based on their abilities of senses such as visual, auditory (noises and sounds), and kinesthetic (tactical and visceral sensations, gustatory; taste and olfactory; smell) or known by VAK-GO $[11,16]$. This distinction of human types will make it easier for nurses to choose the NLP technique that will be used in the intervention.

The selection of the NLP technique consists of several procedures, as rational, identification, description of the perception system, identification of alternative perceptions, modification, homework assignment, and follow-up [7]. NLP techniques include sensory acuity, anchors, modeling, reframing, rapport, pacing, and leading, six-step framing, mirroring circle excellence, and flexibility $[9,11,13,17]$.

Based on the analysis of communication in NLP, nurses must know the purpose of communication with the patient to change the patient's mindset and behavior [9]. Therefore, before communicating, we must identify the purpose of the communication, the material to be conveyed, and how to convey it.

\subsection{NLP intervention}

According to [7, 9-15] NLP interventions were carried out with different techniques and time or length of treatment sessions.

NLP Technique consists of sensory acuity, reframing, anchoring, rapport, pacing, and leading. This technique is done for 10 sessions in 5 weeks. The first session begins with a meeting, creating a good atmosphere, explaining the program, goal, content, and program processes, the second session includes digital auditory methods, the third session is negative framing, the fourth session covers positive framing, the fifth is includes reframing, the sixth session is modeling, the seventh session is self-discovery, the eighth session is stacking anchors, the ninth session is collapsing anchor, and the last session is evaluation and discussion [7]. Meanwhile [9] uses 4 NLP pillars for implementation: outcomes, flexibility, sensory acuity, and rapport. Without explaining how long the implementation will take.

Divide NLP into three categories: presupposisi, rapport, and pacing \& leading, and metaphora. A presupposisi is the initial stage of counseling or what is called initial data, either from friends of clients, closest students, or from counseling forms. Rapport and Pacing \& Leading in this study create an equal atmosphere between nurse and 
patient, by continuously sending signs through body language and verbal language that expresses respect and responses [10].

Performed in three stages using the NLP anchor technique, circle of excellence, and modeling. The anchor technique that is carried out will bring up all the resources within yourself, focusing on the positive things that have been felt, the successes that have been achieved, so that the self will feel empowered and able to see the future with confidence. Followed by the circle of excellence technique by absorbing positive energy from people who are considered to have advantages, based on experience trying to feel the characteristics of a confident person that is known, trying to be a confident character that is perceived according to each experience and making a person feel he has the ability and positive energy like someone perceived. And also the modeling techniques that are the basis of NLP itself in order to be able to do something as well as the experts, this will make someone have the motivation to do something like an expert in the desired field. All the processes of forming positive thinking and personal change for the better [11].

Divided into four stages, first (material understanding treatment), second (NLP rationalization, establishing good relationships, determining the expected output), third (NLP therapy), and fourth (post-test) [12]. [13] The techniques of NLP are reframing, six-step framing, anchoring, and mirroring. These techniques are the techniques most frequently used.

Techniques used in NLP counseling include reframing, anchoring, rapport, criteria, cause and effect, complex equivalence, presuppositions, pacing current experience, neurological level, and mirroring [14]. While the study [15] the intervention consisted of 4 sessions for 2 weeks on average, each session lasted from 60 to 120 minutes with a session break of no more than three days. Family members were encouraged to join some of these sessions, especially in health education.

NLP was applied to the experimental group, and the training program using NLP is for a period of 3 months to cover 24 units or 2 units per week with an average duration of 40-60 apiece. The NLP program consists of a mixture of styles, goal setting, time management, assertiveness skills, effective communication, relaxation skills, and internal representations models based on Skills for Making Change Happen. Combined programs and techniques of NLP that are highly effective and have fast results in the treatment of test anxiety [18]. 


\subsection{Risk of Bias}

This study has a diverse population so that biased factors occur, so further research is needed to find a uniform population. The database used is mostly found on Garuda and uses Indonesian so that the breadth of the discussion cannot be generalized.

\subsection{Limitations}

We did not find that the NLP intervention was carried out at the hospital, so the population keyword for hospital OR hospital had no effect in this study.

\subsection{Research implications}

NLP can be done to overcome anxiety with provisions; identify patients using VAK-GO so that it is easy to determine the NLP intervention technique to be carried out, and develop rapport before implementing it.

\section{Conclusion}

The results showed that there was an effect of NLP on anxiety. NLP can improve knowledge, skills and attitudes, communication skills, self-management, mental health, reduce work stress, and self-efficacy. The biggest role of NLP therapy is to help humans communicate better with themselves, reduce unexplained fear, control negative emotions, and anxiety.

\section{Funding}

This work was supported by the Department of Research and Community Service of STIKES Jayapura - Papua - Indonesia.

\section{Acknowledgement}

The authors would like to thank their colleagues for their contribution and support to the research. We are also thankful to all the reviewers who gave their valuable inputs to the manuscript and helped in completing the paper. 


\section{Conflict of Interest}

The authors have no conflict of interest to declare.

\section{References}

[1] American Psychological Association. (2020). Anxiety. Washington D. C.: APA.

[2] World Health Organization. (2017). Depression and Other Common Mental Disorders: Global Health Estimates. Geneva: World Health Organization.

[3] Udawiyah, R., Ariani, N. K. P. and Lesmana, C. B. J. (2019). Prevalensi kecemasan pada caregiver pasien kanker di RSUP Sanglah Periode Januari 2019. Jurnal Medicina, vol. 50, issue 3, pp. 470-473.

[4] Kemenkes RI. (2016). Peran Keluarga Dukung Kesehatan Jiwa Masyarakat. Retrieved from https://www.kemkes.go.id/article.

[5] Videbeck, L. S. (2011). Psychiatric Mental Health Nursing (5 $5^{\text {th }}$ ed.). Philadelphia.

[6] Stuart, W. G. (2012). Buku Saku Keperawatan Jiwa (5 $5^{\text {th }}$ ed.). Jakarta: EGC.

[7] Triana, I. K. D. L. and Yanti, N. P. E. D. (2018). Neuro-Linguistic Programming: Solusi Tingkatkan Self-Efficacy Perawat Di Rumah Sakit "Neuro-Linguistic Programming: A Solution to Improve Nurse's Self-Efficacy at Hospital. Jurnal BIMIKI, vol. 6, issue 2, pp. 18-27.

[8] Rezakhani, S. Z. F. (2015). The Impact of Neuro-Lingustic Programming on the Change of Coping Strategies of Women with Marital Dissatisfaction. Saussurea, vol. 3, issue 1, pp. 103-114.

[9] Rustan, E. and Hasriani, H. (2020). Communication Pattern Between Nurses and Elderly Patients through a Neuro-Linguistic Programming Approach. Jurnal Studi Komunikasi, vol. 4, issue 1, pp. 75-89.

[10] Hadi, F. Z. and Zubaidah, Z. (2015) Pemanfaatan Konseling Neuro Linguistic Programming dalam Mengatasi Kesulitan Belajar Siswa Sekolah Dasar. Jurnal Dakwah Risalah, vol. 26, issue 4, pp. 174-182.

[11] Zahro, N. K. (2017). Pelatihan Neuro Linguistic Programming (NLP) untuk Meningkatkan Kepercayaan Diri. Persona: Jurnal Psikologi Indonesia, vol. 6, issue 1, pp. 40-51.

[12] Weldani, F. and Muhammad, H. (2015). Penerapan terapi NLP (Neuro Linguistic Programming) untuk menurunkan kecemasan dalam melakukan lompat kangkang pada siswa kelas X. Jurnal Pendidikan Olahraga dan Kesehatan, vol. 3, issue 2, pp. 303-307. 
[13] Kusuma, R. and Purwoko, B. (2018). Studi Kepustakaan Mengenai Landasan Teori dan Praktik Konseling Neuro Linguistic Programming (NLP). Jurnal Mahasiswa Bimbingan Konseling UNESA, vol. 8, no. 1.

[14] Imah, M. T. and Purwoko, B. (2018). Studi Kepustakaan Penerapan Konseling Neuro Linguistic Programming (NLP) dalam Lingkup Pendidikan. Jurnal Mahasiswa Bimbingan Konseling UNESA, vol. 8, issue 2, pp. 10-19.

[15] Peng, Y., et al. (2015). The Effect of a Brief Intervention for Patients with Ischemic Stroke: A Randomized Controlled Trial. Journal of stroke and cerebrovascular diseases. The Official Journal of National Stroke Association, vol. 24, issue 8, pp. 1793-1802, doi.org/10.1016/j.jstrokecerebrovasdis.2015.04.009.

[16] Passmore, J. and Rowson, T. (2019). Neuro-Linguistic Programming: A Review of NLP Research and the Application of NLP in Coaching. International Coaching Psychology Review, vol. 14, issue. 1, pp 57-69.

[17] Abdivarmazan, M. and Sylabkhori, Z. (2016). Effectiveness of Training of NeuroLinguistic Programming (NLP) Strategies on Reducing Social Anxiety. World Scientific News, issue 60, pp. 67-77.

[18] Fakehy, M. and Haggag, M. (2016). The Effectiveness of a Training Program using Neuro - Linguistic Programming (NLP) to Reduce Test Anxiety in Consideration of Biological Feedback. International Journal of Behavioral Research \& Psychology, vol. 4, issue 1, pp. 173-177.

[19] Afifa, Z. N. M., et al. (2020). The Improvement of Teachers' Pedagogical Competence in Recognising Students Characteristics with Neuro-Linguistic Programming (NLP) In Indonesia. International Journal of Innovation, Creativity and Change, vol. 13, issue 8, pp. 762-780.

[20] Wikanengsih, W. (2012). Menerapkan Neurolinguistic Programming (NLP) dalam Pembelajaran. Semantik, vol. 1, issue 1, pp. 31-45. 